\title{
Evidence of topographic disequilibrium in the Subarnarekha River Basin, India: A digital elevation model based analysis
}

\author{
Shantamoy Guha ${ }^{1, *}$ (i) and Priyank Pravin Patel ${ }^{2}$ \\ ${ }^{1}$ Earth Sciences Discipline, Indian Institute of Technology, Gandhinagar 382 355, India. \\ 2 Department of Geography, Presidency University, Kolkata 700 073, India. \\ *Corresponding author.e-mail: shantamoy.guha@iitgn.ac.in
}

MS received 29 January 2017; accepted 20 April 2017; published online 16 October 2017

Cratonic areas experience complex process-response changes due to their operative endogenic and exogenic forces varying in intensity and spatiality over long timescales. Unlike zones of active deformation, the surface expression of the transient signals in relatively tectonically stable areas are usually scant. The Subarnarekha River Basin, in eastern India, is a prime example of a Precambrian cratonic landscape, overlain in places by Tertiary and Quaternary deposits. A coupled quantitative-qualitative approach is employed towards deciphering tectonic and geological influences across linear and areal aspects, at the basin and sub-basin scale. Within this landscape, the transient erosional signatures are explored, as recorded in the disequilibrium conditions of the longitudinal profiles of the major streams, which are marked by a number of waterfalls at structural and lithological boundaries. Mathematical expressions derived from the normalized longitudinal profiles of these streams are used to ascertain their stage of development. Cluster analysis and chi plots provide significant interpretations of the role of vertical displacements or litho-structural variations within the basin. These analyses suggest that a heterogeneous, piece-meal response to the ongoing deformation exists in the area, albeit, determining the actual rate of this deformation or its temporal variation is difficult without correlated chronological datasets.

Keywords. Neotectonics; longitudinal profile; DEM; morphometry; geological structure; stream response.

\section{Introduction}

Landforms are the product of the coupling between tectonic and denudational processes. Tectonic forces change the relative elevation of the surface, thereby increasing the potential energy for erosion (England and Molnar 1990), and also exert an influence on the magnitude and intensity of denudation (Thornbury 1954). Lithological and structural characteristics provide a template to gauge the effectiveness of these erosional process, e.g., that of a river either at the basin scale (Nag and Chakraborty 2003), or at the reach scale (Strecker et al. 2003), and furthermore, can themselves be discerned from the nature of erosional activity that has occurred (Duncan et al. 2003;

Supplementary material pertaining to this article is available on the Journal of Earth System Science website (http://www. ias.ac.in/Journals/Journal_of_Earth_System_Science). 
Ahmadi et al. 2006). However, quantitative insight into the interaction between tectonics and erosional processes in the context of geologic and structural formations is scant and poorly understood in terms of the resultant topography (Burbank et al. 1996).

Traditionally, cratonic areas or 'Shields' have been considered to be stable enough to showcase prominent effects of neotectonics (Valdiya 2001; Sangode et al. 2013). However, transient characteristics are conspicuous in many parts of the world underlain by old and relict topography (Prince et al. 2011; Mandal et al. 2015). The Singhbhum craton, in eastern India, portrays similar transient characteristics in the form of knickpoints along the longitudinal courses of many streams coursing through it, albeit it has been only accounted for Precambrian tectonics, due to its long and complex evolutionary history (Sarkar 1982; Saha 1994). To investigate the tectonic inference from the terrain, it is paramount that tectonic indices be also coupled with the corresponding litho-structural setting of the area (Lima and Binda 2013; Azañón et al. 2015).

In this study, we attempt to identify the tectonic and structural controls on river channel form in the Subarnarekha River Basin (prominently underlain by Precambrian rocks of the Singhbhum craton) via geomorphic and morphometric analysis. A dual framework has thus been used in this study, incorporating qualitative methods to decipher the existent geologic and structural influences, alongside quantitative measures for ascertaining probable tectonic effects on the longitudinal channel profile development. Qualitative measures include identification of knickpoints using a digital elevation model and correlating it with the bedrock geology and structure. Quantitative measures involve enumeration and mapping of selected indices of active tectonics for the studied Subarnarekha River Basin.

\section{Study area}

Draining a catchment area of approximately 19,000 $\mathrm{km}^{2}$, the River Subarnarekha is an important eastward flowing river in eastern India. It rises near Nagri village $\left(23^{\circ} 18^{\prime} \mathrm{N}, 85^{\circ} 11^{\prime} \mathrm{E}\right)$, just north of Ranchi (major city \#1 in figure 1) at an elevation of $\sim 610 \mathrm{~m}$ in the Ranchi district of Jharkhand, drains the southeastern portion of the Chotanagpur Plateau, cuts through the Dalma Hill Range at Chandil $\left(22^{\circ} 54^{\prime} \mathrm{N}, 86^{\circ} 02^{\prime} \mathrm{E}\right)$, just upstream of Jamshedpur (major city \#2 in figure 1) and debouches into the Bay of Bengal at Talshari $\left(21^{\circ} 33^{\prime} \mathrm{N}, 87^{\circ} 23^{\prime} \mathrm{E}\right)$ in the Baleswar district of Orissa, after traversing a distance of about $395 \mathrm{~km}$.

The prominent hill ranges within this basin are situated above an average elevation of $450 \mathrm{~m}$ from the mean sea level, and are flanked by prominent denudational scarps situated at elevations of 300 $450 \mathrm{~m}$ (figure 1). The Dalma Range stands within this landscape and the presence of lateritic duricrust at altitudes of 600 and $900 \mathrm{~m}$ are thought to represent two uplifted palaeo-surfaces (Mahadevan 2002). A major portion of the total basin area lies below $300 \mathrm{~m}(\sim 80 \%)$, incorporating the undulating plains of the lower reaches of the rivers that have their sources in the above hills, and which are herein overlain by considerable floodplain deposits (figure 1).

The entire basin can be subdivided into three broad geological units, i.e., Archaean-Precambrian formations, Tertiary formations and Quaternary alluvium. Considerable portions of the upper and middle basin areas are underlain by exposed Precambrian metamorphic and igneous rocks. In its lower reaches, the main Subarnarekha River channel interacts with younger formations as well as with the unconsolidated deposits of Tertiary and Quaternary sediments (figure 2). South of the Dalma Range, the ridges of the Singhbhum Shear Zone (SSZ) splay arcuately along the west bank of the Subarnarekha's course, being dissected by the river at Chandil and go on to form sharp bends further east (figure 2). Rejuvenations of streams adjacent to and within the SSZ have been reported, caused by surficial movements on a minor scale, and accounted for by the low seismic signatures recorded in this area (Banerji et al. 1970; Mukhopadhyay 1977; Mahadevan 2002).

The average annual rainfall within the basin ranges between 1100 and $1400 \mathrm{~mm}$ (figure 3) (Chatterjee et al. 2014), with this amount being received almost entirely during the monsoonal months of June-September, as is reflected in the strongly leptokurtic nature of the stream flow hydrographs of the rivers (Yarrakula et al. 2010). In addition to these, the Subarnarekha is also a major transporter of heavy metals from its upstream region (Giri et al. 2013), with significant mineral resources and mining centers being located along its course, particularly in the vicinity of Ghatshila (major city \#3 in figure 1).

Using a combination of the principal geologic and geomorphologic units, the basin terrain can be divided into three broad units, i.e., the upper 


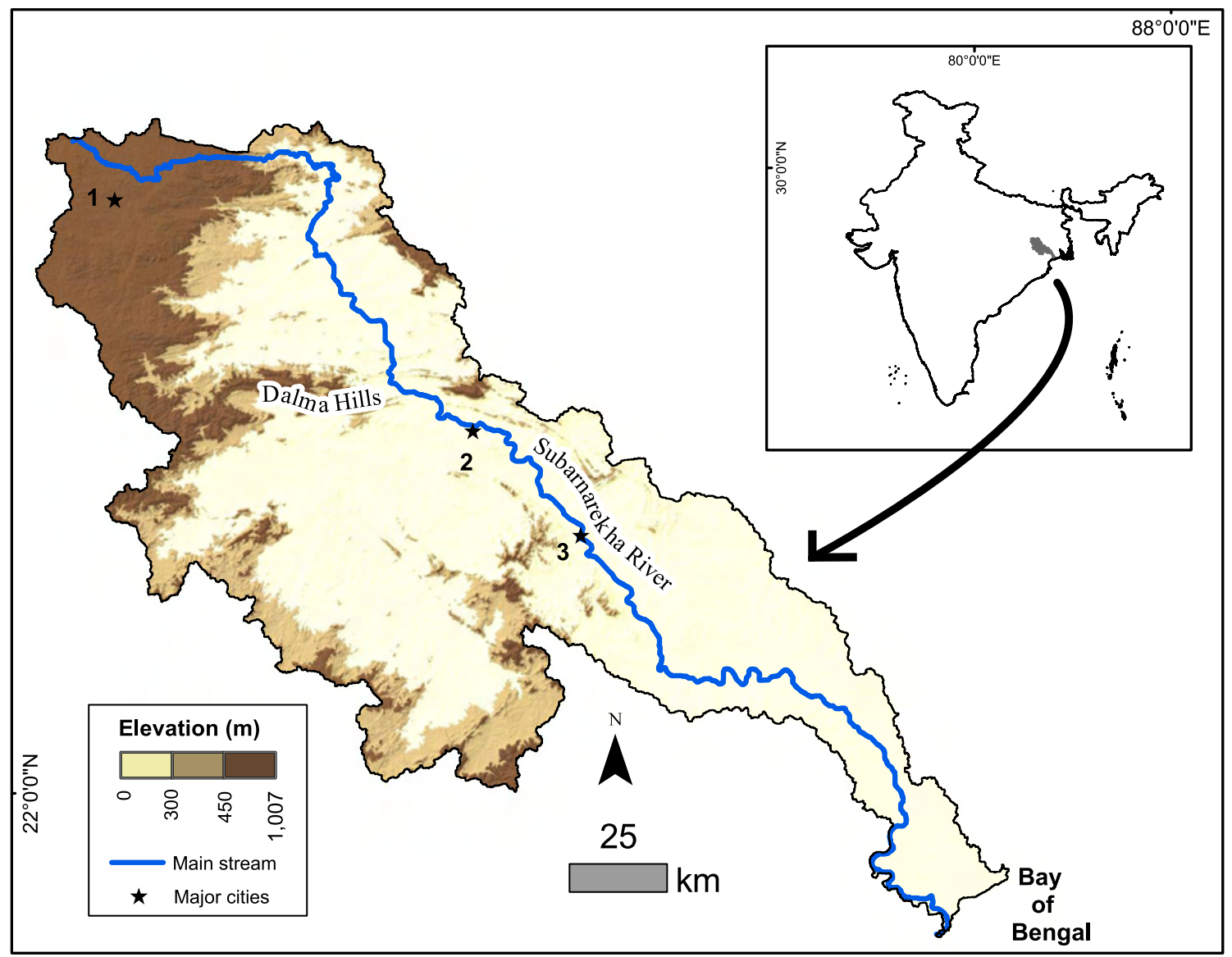

Figure 1. SRTM $90 \mathrm{~m}$ digital elevation model showing the topography and main channel of the Subarnarekha river across its basin. The indexed points are cities numbered as 1: Ranchi, 2: Jamshedpur, 3: Ghatshila.

portion comprising of the dissected Precambrian Chotanagpur Plateau complex in the north and the dissected Singhbhum granite complex in the southwestern part (from the source area near Ranchi till the demarcated shear zones north of Chandil and also southwest of the demarcated shear zone south of Chandil), the middle reaches formed by the rugged Dhanjori and Dalma Hills section (the basin portion lying between the demarcated shear zones north and south of Chandil) and finally, the lower stretches comprising of the gently undulating alluvial plains of Tertiary deposits that are overlain by unconsolidated Quaternary sediments (the southeastern portion of the basin lying to the east of the demarcated southern shear zone and stretching till the Bay of Bengal coastline) (refer to both figures 1 and 2).

\section{Methods and calculations}

Geomorphic characterization, based on tectonic and geologic formations is tricky and subjective, as the natural processes involved are complexly interrelated and dynamic in nature. Traditional studies have usually examined the tectonic framework using well-defined indices (Burbank and Anderson 2011), with their underlying assumptions of a uniformity in rock strength (geology) and climatic characteristics (Kale and Shejwalkar 2007). However, across broader spatial scales and in areas of heterogeneous lithological characteristics, such assumptions have to be generalized and thereby identification of tectonic indications become difficult. Hence, in the present study, a holistic approach is presented where traditional indices (hypsometric integral, slope area plot, normalized longitudinal profiles, steepness index) were included along with the powerful tool, chi plot.

\subsection{Extraction of tectonic and morphometric parameters}

Shuttle Radar Topographic Mission (SRTM) ca. $90 \mathrm{~m}$ Digital Elevation Model (DEM) data has been extensively used in geomorphic studies, including comparisons with synthesized surfaces derived from numerical models (Harbor and Gunnell 2007; Colberg and Anders 2014; Willett et al. 2014). In 


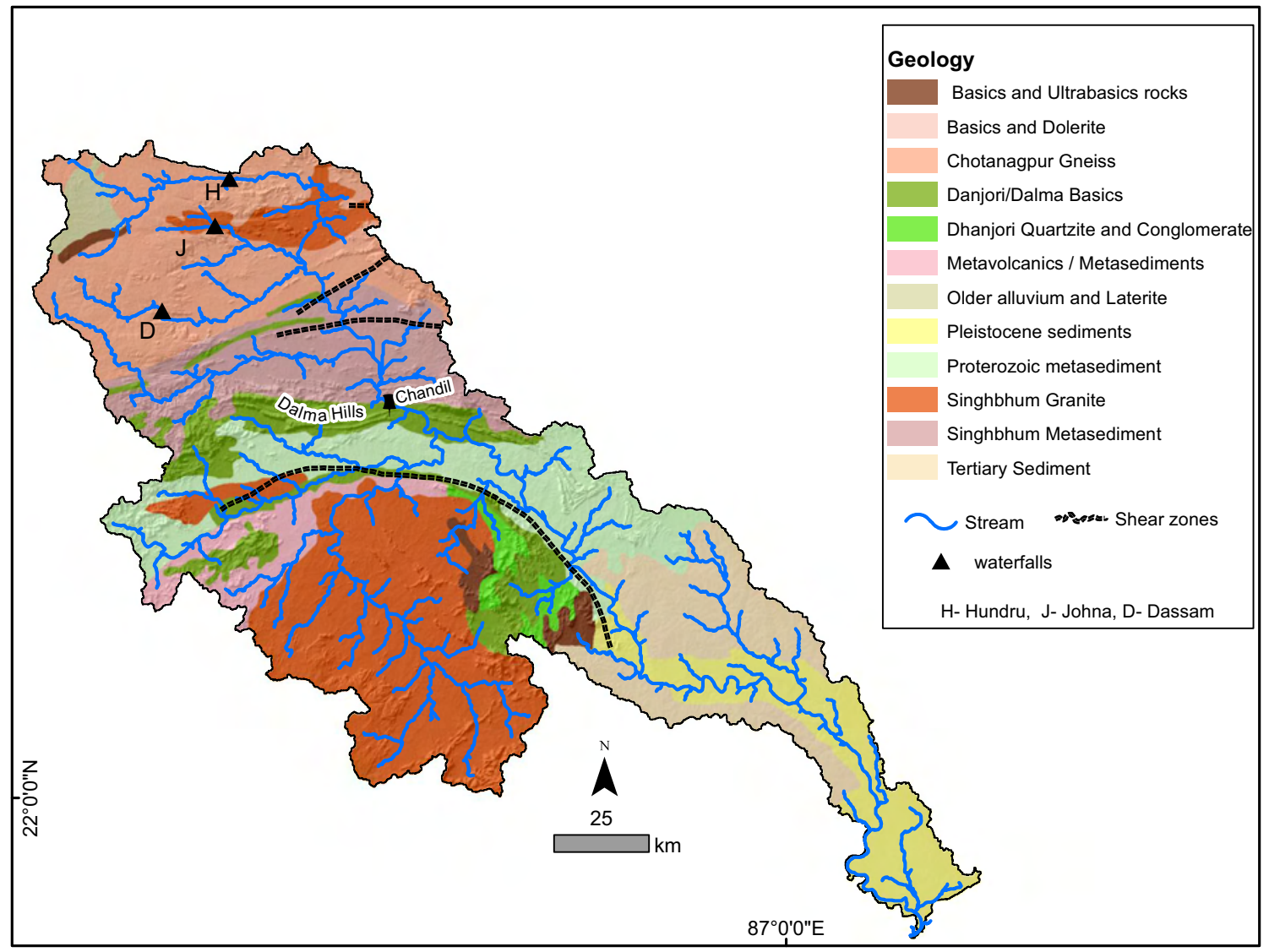

Figure 2. Bedrock geology and shear zones (after Geological Survey of India) within the Subarnarekha basin, overlain by a detailed drainage map.

the present study, therefore, SRTM DEM is used to derive the tectonic indices for the Subarnarekha River basin. For identifying the regional patterns of these indices, the main basin has furthermore been divided into 12 sub-basins using the Soil and Water Analysis (SWAT) model (Gassman et al. 2007), using specified stream junction points. Matlab based Geomorphtools (Whipple et al. 2007) and TopoToolbox (Schwanghart and Kuhn 2010) have been used to calculate most of the tectonic and morphometric indices. To analyze the longitudinal profiles, we have extracted the principal stream and its tributaries by manual pour point.

\subsection{Plotting normalized longitudinal profiles with best-fit curves}

Although the breaks in a river's longitudinal profile (i.e., an abrupt channel elevation or channel slope change) are prime indicators of structural and lithological alterations across its course, the marked difference of magnitude between these changes, i.e., that of the elevation difference from a river's source to its mouth (its fall) vs. that of its entire channel length from the source to mouth, introduces the problem of scaling both these variables (Lee and Tsai 2010). In order to nullify this scaling factor, a normalization procedure has been applied to the main channel, as well as to the examined tributaries by manual pour point selection method (see supplementary figure S2 for the watersheds delineation). Four mathematical functions were used to compare and derive a best-fit curve on the respective profiles to ascertain the stage of development of the respective basins, as well as inculcate a process-based understanding. These are as follows:

The linear function, $y=a x+b$,

The exponential function, $y=a e^{b x}$,

The logarithmic function, $\quad y=a \ln x+b$,

The power regression model, $y=a x^{b}$,

In these equations, $y$ is the elevation (it is calculated as $h / h_{0} ; h$ is the elevation of each point, $h_{0}$ is the elevation of the source), $x$ is the length of the river $\left(l / l_{0} ; l\right.$ is the distance of any discrete 


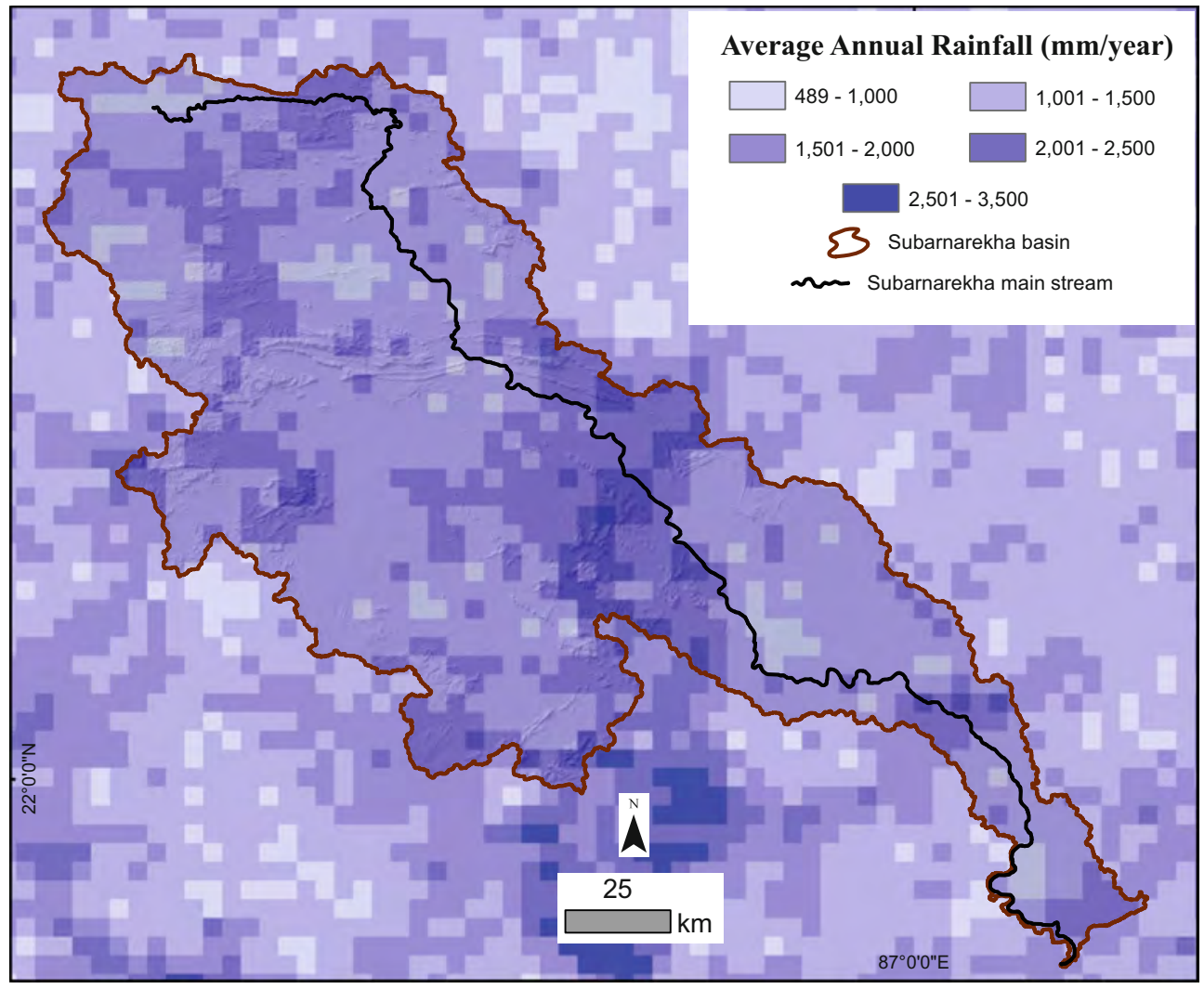

Figure 3. Annual average rainfall distribution over Subarnarekha River basin. Rainfall data after Bookhagen and Strecker (2008) and Bookhagen and Burbank (2010). The precipitation data is resampled TRMM 2 B31 v6 product of $5 \mathrm{~km}$ spatial resolution and obtained from http://www.geog.ucsb.edu/ bodo/TRMM/.

point from the source, $l_{0}$ is the total length of the stream), while $a$ and $b$ are coefficients.

\subsection{Extracting concavity and steepness indices}

The combination of the conservation of mass statement along with the bed shear stress model can be reproduced as the following equation (Howard and Kerby 1983; Howard 1994):

$$
\frac{\partial z}{\partial t}=U(x, t)-K(x, t) A(x, t)^{m}\left|\frac{\partial z}{\partial x}\right|^{n} .
$$

It is assumed that the topography is in a steady state, i.e., the rate of uplift is balanced by the erosion process $(\partial z / \partial t=0)$ (Whipple and Tucker 1999; Whipple et al. 2007). Equation (5) then can be written as:

$$
\left|\frac{d z}{d x}\right|=\left(\frac{U}{K}\right)^{1 / n} A(x)^{-m / n},
$$

or

$$
S=k_{s} A^{-\theta}
$$

where the local channel slope is represented as $S, A$ is the upstream drainage area, and $k_{s}$ and $\theta$ are referred to as the steepness and concavity indices, respectively. Therefore, there is an inherent power law relationship between the channel slope and the drainage area (Flint 1974). This relationship is used in the present study by calculating the normalized steepness index $\left(k_{s n}\right)$ and the concavity index $(\theta)$, for the main stream flowing through the entire Subarnarekha basin as well as for the principal streams of each of the sub-basins.

The longitudinal profiles of the main river and its principal tributaries, along with the geologic formations over which they propagate, have been considered while analyzing the geologic constraints and influences apparent in the development of these profiles. The principal and tributary stream courses are used for extraction of slope-area plots to estimate the normalized steepness index $\left(k_{s n}\right)$ and the concavity index $(\theta)$, with the reference concavity $\left(\theta_{\text {ref }}\right)$, using the help of geomorphtools 
(available at http://geomorphtools.geology.isu.edu/ Tools/StPro/StPro.htm). Reference concavity is the average concavity in the undistributed channel segments and generally falls between 0.35 and 0.65 (Wobus et al. 2006a, b). Generally, researchers have used a reference concavity value of 0.45 (Snyder et al. 2000; Wobus et al. 2006a, b; Molin and Corti 2015). The batch tool from the same application generates a vector layer containing the normalized steepness index $\left(k_{s n}\right)$, for each $500 \mathrm{~m}$ reach segment of these rivers and for all streams having a critical area above $20 \mathrm{~km}^{2}$ (taken as the threshold for channel initiation in this study) (see supplementary figure $\mathrm{S} 1(\mathrm{a}-\mathrm{h})$ for depictions of the derived concavity and steepness plots of selective sub-basins).

\subsection{Deriving the chi plots}

Using the algorithm developed by Schwanghart and Kuhn (2010), the chi plots (Perron and Royden 2013), were generated for the main stream as well as for its tributaries. Traditional slope-area plots generally have numerous uncertainties because of noisy topographic data. This causes a considerable scattering of the dataset, which as a result, has to undergo a logarithmic binning process (Wobus et al. 2006a, b; Perron and Royden 2013). Therefore, the horizontal spatial coordinate is transferred into chi $(\chi)$, where the independent variable is the less noisy elevation data. The general form of the equation is:

$$
\begin{gathered}
z(x)=z(x b)+\left(\frac{U}{K A o}\right)^{1 / n} \chi \\
\chi=\int_{x b}^{x}\left(\frac{A o}{A(x)}\right)^{m / n} d x .
\end{gathered}
$$

The integration is performed from the downstream end of the stream (base level elevation $x_{b}$ ) towards the upstream direction (elevation $x$ ). Here, $U$ and $K$ are the same as defined in the preceding section, while $A(x)$ is the drainage area for every discrete point $x$. This formulation removes the effect of the drainage area and therefore the chi profiles are independent of spatial scale. Therefore it is useful in a dual way, for comparing different drainage basins and for also comparing profiles within a single drainage basin (Perron and Royden 2013). From equation (8), it is quite evident that in the steady state, the chi profile becomes linear. Thus, if there is any transient signal in the erosion, then these will be recorded as deviations from the linear trend.

\subsection{Hypsometric analysis and statistical derivations}

We have also prepared grid-based Hypsometric Integral (HI) values for the entire watershed. These grid-based HI values provide a better understanding for differentiating the geologic imprints and tectonic processes. However, without proper statistical conversion, the extracted grid-based HI values are generated in a random pattern and do not show proper clustering for specific tectonically active or geologically distinct regions (Pérez-Peña et al. 2009). Therefore, Moran's I (Moran 1950) is used to observe whether there is any spatial autocorrelation. Moran's $I$ is given as:

$I=\left(\frac{N}{\sum_{i} \sum_{j} W i j}\right)\left[\frac{\sum_{i} \sum_{i} w_{i j}\left(x_{i}-\mu\right)\left(x_{j}-\mu\right)}{\sum_{i}\left(x_{i}-\mu\right)^{2}}\right]$

where $N$ is the number of observations, $w_{i j}$ is the element in the spatial weights matrix which is corresponding to the element pair $(i, j), x_{i}$ and $x_{j}$ are observations for locations $i$ and $j$ and the mean is $\mu$. The standardized $z$ score is then calculated using the following equation:

$$
z=\frac{I-E(I)}{S_{E(I)}}
$$

where $I$ is an empirical value which is calculated from the total sample, $E(I)$ is the calculated mean of the random distribution and $S_{E(I)}$ is the standard deviation of $E(I)$. The $z$ score and the $p$ values aid in affirming the acceptance or rejection of the null hypothesis.

The Moran's $I$ is a statistic value which relies on the global means of autocorrelation, whereas there might be local associations between the grids depending on their respective values. To check the location and extent of these clustered values of the $\mathrm{HI}$, we have used the Getis-Ord $\mathrm{G}_{\mathrm{i}}$ statistic (Ord and Getis 1995), which is defined as:

$$
G_{i}^{*}=\frac{\sum_{j} w_{i j}(d) x_{j}}{\sum_{j} x_{j}}
$$

This aids in identifying the hotspots within the basin where the number of neighbours are taken into account to calculate the cluster pattern (Ord and Getis 1995).

\subsection{Lineament extraction}

The lineaments across the basin area were extracted using the LINE (Lineament Extraction) module 
available for this purpose in PCI Geomatica (Kocal et al. 2007; Geomatics 2015). The six inputs required to extract the lineaments are respective values for the Radius of filter (in pixels), the Threshold for edge gradient, the Threshold for curve length, the Threshold for line fitting error, the Threshold for angular difference and the Threshold for linking distance parameters (Abdullah and Abdoh 2013; Geomatics 2015). The values were input following the different threshold values as suggested by Prasad et al. (2013), Raj and Ahmed (2014) and Shankar et al. (2016). The derived curvilinear features were then converted to vectors that were overlain on Google Earth imagery for visual comparison based accuracy assessment, suitably modified thereafter and finally extracted after such confirmation. These were clipped using a mesh of $1 \mathrm{~km}^{2}$ grids overlain over the basin and their density in each grid enumerated for eventual isopleth mapping.

\section{Results and discussion}

\subsection{Concavity and steepness indices}

The individual streams of the sub-basins have highly segmented longitudinal reaches with marked variability in their respective concavities. In spite of these, the concavity index falls in a narrow range for the various sub-basins and satisfies the prevalent values, i.e., 0.3-1.0 (Tarboton et al. 1991; Willgoose et al. 1991). Only a few of the basins exhibit relatively higher values $(>1.2)$, as has been noted earlier in other studies (Sklar and Dietrich 1998). Steepness values of the most prominently concave portions decrease systematically from upstream towards downstream (table 1). In the upstream area (Basin numbers 1-8 except 7 in table 1 ), the values of the average $k_{s n}$ are higher (17.5-64.7) than those in the downstream (2.03-17). As the steepness values are not significantly different in different sections of the basins, it can be enumerated that the difference in the magnitude of the erosional processes is not extreme. As the landscape is assumed to remain in a steady state condition, therefore the regional uplift rate and erodibility of the rocks are also dissimilar across the drainage basin, even though again, this does not vary markedly.
Table 1. Values for concavity $(\theta)$ and steepness $\left(k_{s n}\right)$ indices of the studied sub-basins.

\begin{tabular}{lll}
\hline Sub-basins & \multicolumn{1}{c}{$\theta^{\mathrm{a}}$} & \multicolumn{1}{c}{$k_{\text {sn }}$} \\
& $0.43 \pm 0.14$ & 8.86 \\
1 & $21 \pm 18$ & 64.6 \\
& $0.48 \pm 0.6$ & 21.1 \\
2 & $1.2 \pm 1.1$ & 64.7 \\
& $0.058 \pm 0.21$ & 19 \\
3 & $16 \pm 4.8$ & 62.3 \\
& $2.3 \pm 3$ & 54.4 \\
4 & $1.3 \pm 0.38$ & 17.9 \\
5 & $1.1 \pm 0.91$ & 29.6 \\
6 & $0.51 \pm 0.36$ & 23.5 \\
7 & $1.1 \pm 0.36$ & 42.7 \\
8 & $0.74 \pm 0.075$ & 17 \\
9 & $0.33 \pm 0.16$ & 12.2 \\
10 & $0.46 \pm 0.2$ & 9.34 \\
11 & $0.52 \pm 0.13$ & 2.03 \\
12 &
\end{tabular}

For the sub-basin locations, see figure 4a. ${ }^{a}$ Most of the river profiles are characterized by segmented river profiles and therefore the different concave sections are present there.

In the absence of substantial data regarding the strength of the different rocks in this region, we have tried to correlate qualitatively between the lithology and $k_{s n}$. Most of the streams in the upper-most basin reaches are underlain by an Archaean-Proterozoic gneissic complex which is hard to erode. Within this particular lithology, the average $k_{s n}$ portrays high values. As the erodibility does not change significantly, the probability of the slow ongoing uplift is evident. Some of the sub-basins show prominent slope-break knickpoints along the courses of their principal stream (refer to Basin numbers 4 and 5 in figure $4 \mathrm{~b}$ ), which is an alternative indication of finite vertical movement, or upstream propagation of a transient wave (Reusser et al. 2004; Haviv et al. 2010). However, it is also accepted that few knickpoints are vertical-steps with a small (relative to the amount of catchment relief) vertical drop which cannot be subscribed merely to a tectonic uplift (refer to Basin number 1 in figure $4 \mathrm{~b}$ ). The overall erosional response of the drainage basin to uplift and subsequent landform sculpting has therefore been piece-meal and heterogeneous, probably in keeping with the postulates of landscape sensitivity and equilibrium as furthered by Brunsden and Thornes (1979), Phillips (1998) and Thomas (2001). 
a

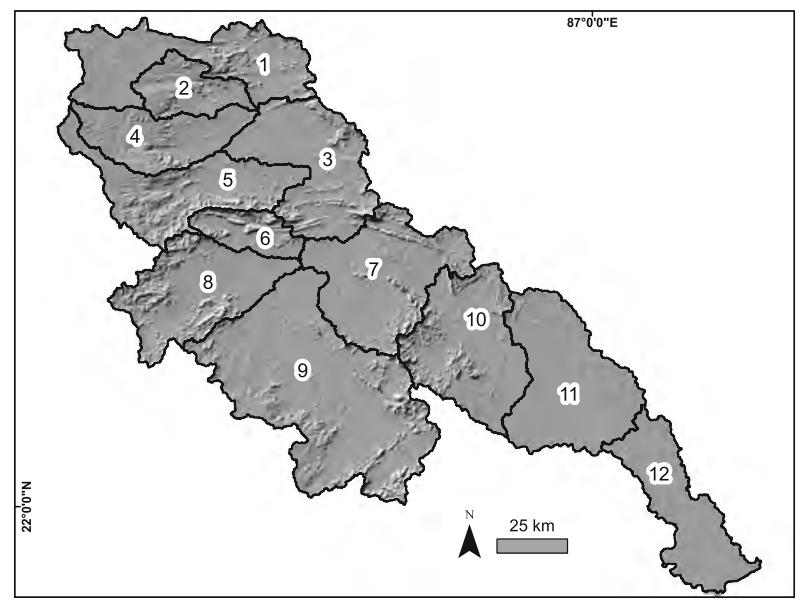

b

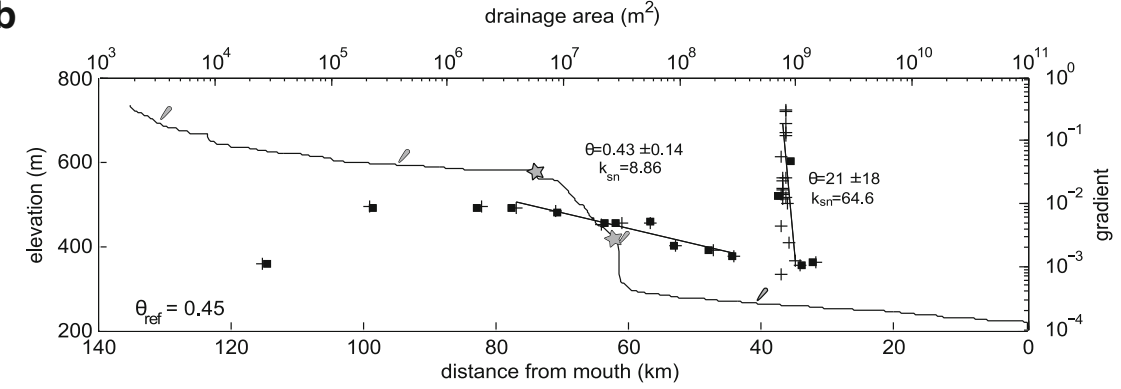

drainage area $\left(\mathrm{m}^{2}\right)$

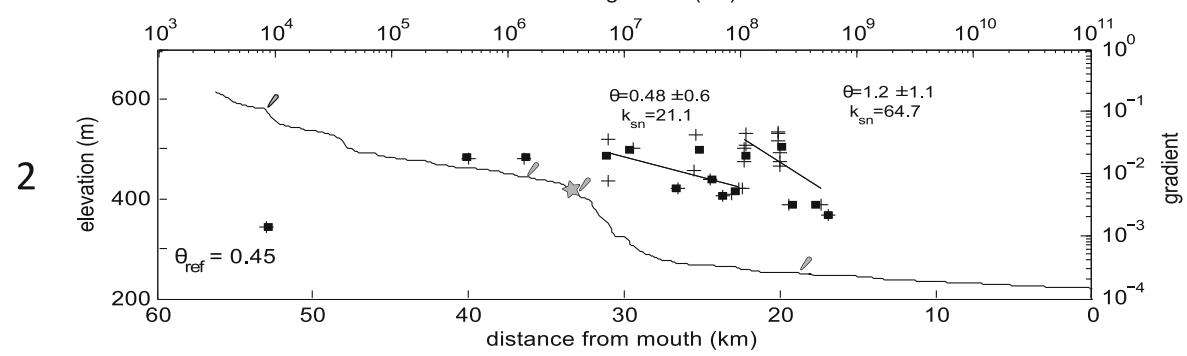

drainage area $\left(\mathrm{m}^{2}\right)$
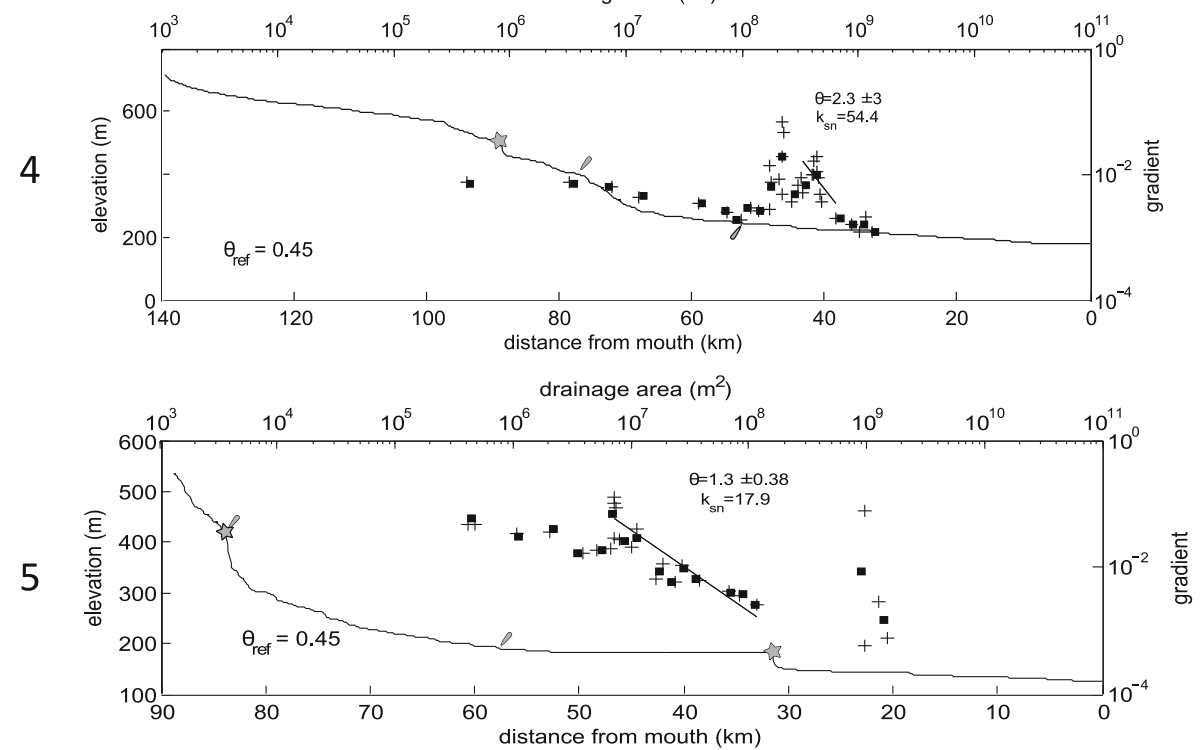

Figure 4. Longitudinal profiles and concavity analysis (a) Sub-basins that are demarcated with SWAT tool. (b) Longitudinal profiles and slope area plots for selected sub-basins. The basin number is denoted on the left-hand side of each sub-plots. The slope is calculated from a contour interval of $20 \mathrm{~m}$. 


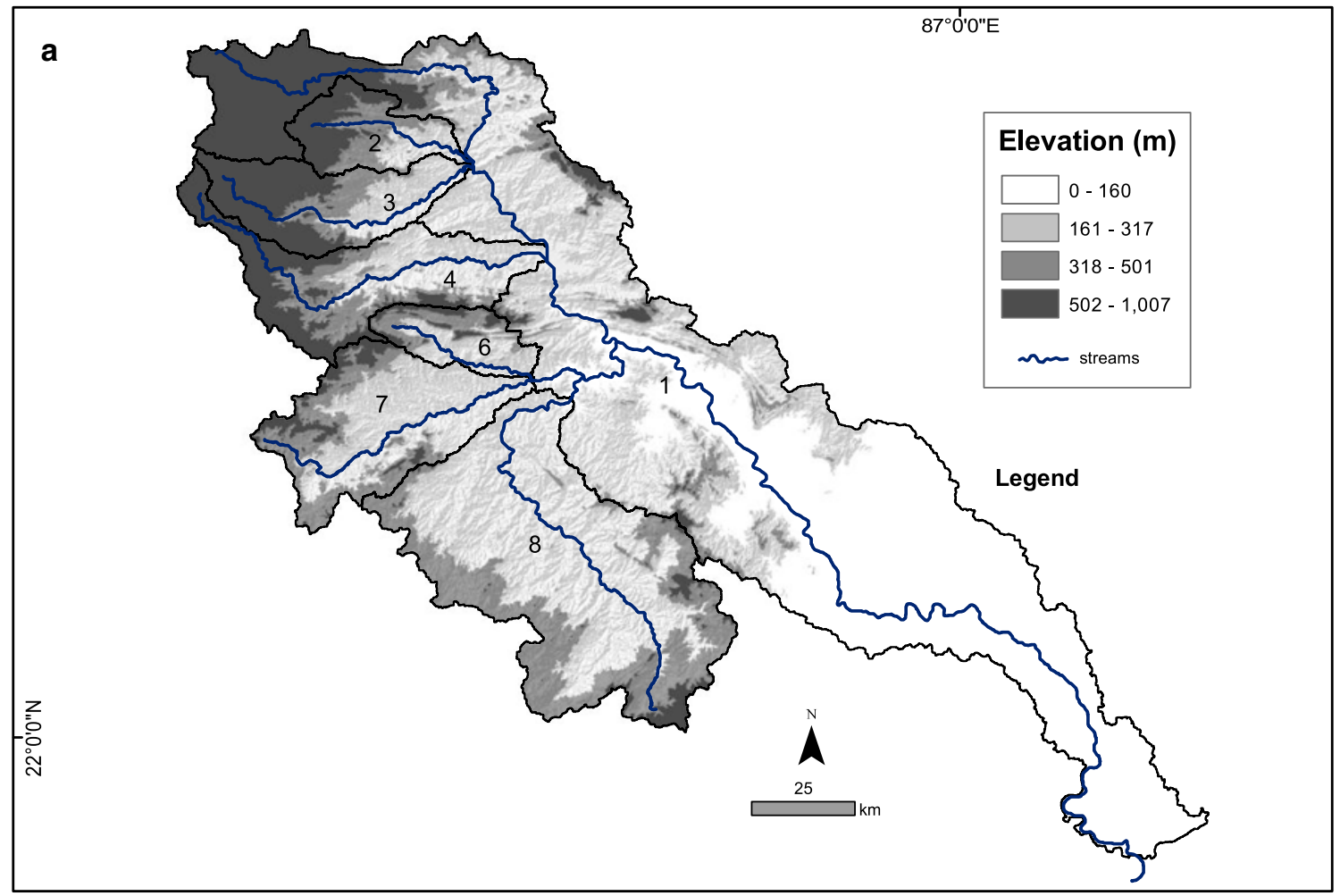

b

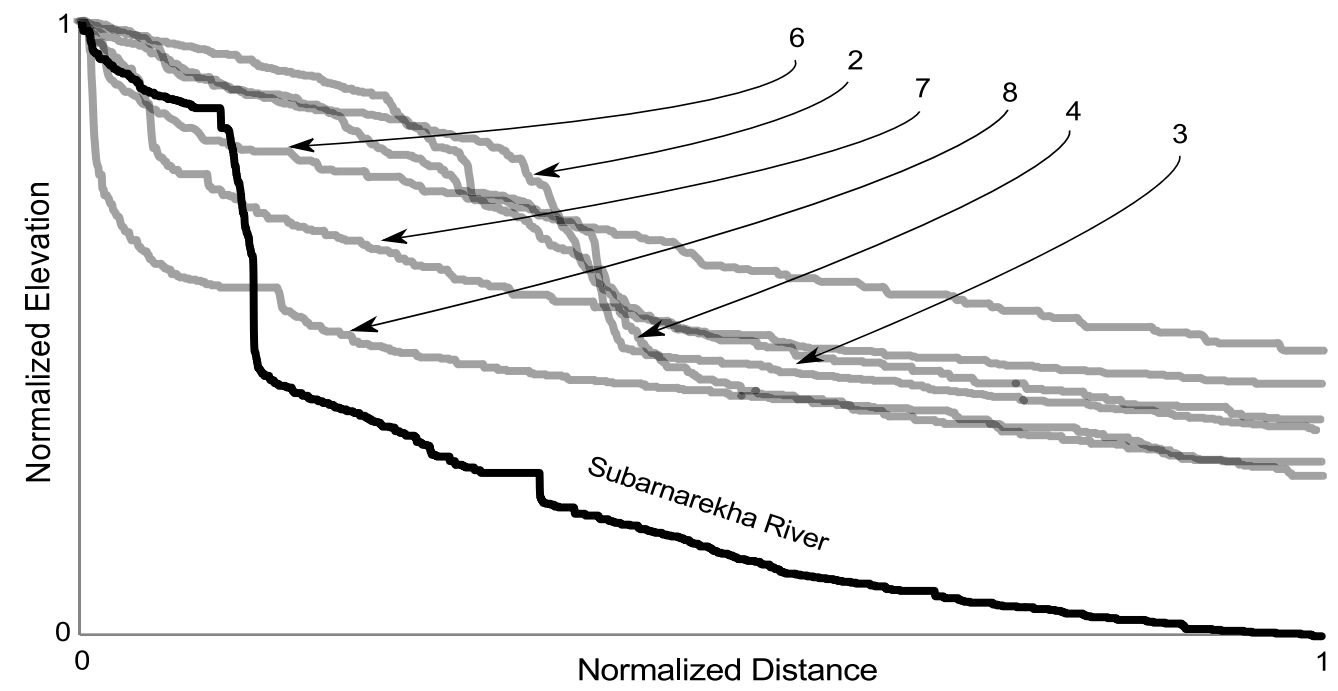

Figure 5. Normalized longitudinal profiles for the sub-basins of Subarnarekha River. (a) Basin number and principal streams considered for the longitudinal plot. (b) Composite plot of normalized longitudinal profiles.

\subsection{Normalized longitudinal profiles}

The longitudinal profile of a river is highly sensitive to changes in the underlying lithology over which it courses or to any sudden relative elevation change arising from tectonic disturbances (Lin and Oguchi 2006; Ambili and Narayana 2014). All the normalized longitudinal profiles, thus obtained, for the main and tributary streams (see supplementary figure S2), have then been superimposed into one figure for comparison (figure 5). When the river bears an excess sediment load which it cannot transport in its entirety, the profile tends towards being linear, while a dynamic equilibrium profile shall attain an exponential function form. With continued erosion and thereby decrease of the grain size downstream, the longitudinal profile form shall best-fit the logarithmic model curve and attains a 
Table 2. Best-fit regression models for different tributaries in Subarnarekha River basin.

\begin{tabular}{lcccc}
\hline Sub-basins & Best fit & $\begin{array}{c}\text { Regression } \\
\text { intercept }\end{array}$ & $\begin{array}{c}\text { Regression } \\
\text { coefficient (b) }\end{array}$ & $\begin{array}{c}\text { Explained } \\
\text { variance }\end{array}$ \\
\hline Subarnarekha & & & & \\
1 & Exponential & 1.2912 & -4.746 & 0.9445 \\
2 & Exponential & 1 & -1.065 & 0.9097 \\
3 & Exponential & 1.0084 & -1.267 & 0.9338 \\
4 & Exponential & 1.0985 & -1.571 & 0.9506 \\
6 & Exponential & 0.883 & -0.68 & 0.9877 \\
7 & Logarithmic & -0.155 & 0.381 & 0.9603 \\
8 & Logarithmic & -0.118 & 0.3119 & 0.9715 \\
\hline
\end{tabular}

graded profile while with further increments of concavity, it will tend towards a power law function model (Kale et al. 2010).

As a stream attains a stable equilibrium, balancing between uplift and erosion, it attains a graded profile (Hack 1973), wherein the best fit model is a logarithmic function. Therefore, the channels which are showing the best fit for a logarithmic profile, are in stable equilibrium with a steady decrease of grain-size downstream. Stream numbers 7 and 8 in figure 5(b) are thus perfect examples of graded profiles. Although these streams are in equilibrium in present forcing, small knickpoints are constantly being eroded to maintain the smooth profile. The sharp break in the normalized profile of the main Subarnarekha channel indicates tectonic or structural forcing in the dynamic equilibrium state. Stream numbers 2, 3, 4 and 6 in the same figure also display this dynamic equilibrium state. The main Subarnarekha River's longitudinal profile also shows an exponential trend which depicts the continuous competition between the forcing in the river basin (table 2 and figure 5b) and the erosion. Here, the river tends towards a dynamic equilibrium between the available sediment and water discharge across distinct tectonic and structural units.

Best fit exponential trend of the most of the channels in the Subarnarekha basin typically portray relatively lower concavity. Neo-tectonically stable terrains usually depict river profiles which are graded. These channels in the upstream portion of the basin propagate mostly over an almost completely granite-gneiss terrain, with very few intrusions of other rocks, nor do they experience abrupt changes in lithology. This seemingly uniform base may have thus played a role in aiding these channels achieve an apparent graded condition. For the other channels (particularly those flowing in the central part of the basin), the varying lithologies underlying the streams, have probably inhibited the attainment of an overall equilibrium condition throughout, as the local thresholds and differing resistances of these rock beds, condition and characterize the channel into distinctive separate segments. Prevalent characteristics display that these streams are in a phase of active degradation to attain stable equilibrium. Ultimately, the non-existence of a power regression model depicts that there has been a persistent and stable deformation component in the Singhbhum craton.

\subsection{Controls on the longitudinal profiles and steepness}

In the Subarnarekha basin, linear channel stretches are evident wherever there is structural control, especially in areas associated and controlled by the SSZ, specifically in a broad zone across the central part of the basin, from west to east. This is particularly evident for the main Surbarnarekha channel from Chandil to Jamsola. Throughout this entire stretch, the river flows over sharply eastward dipping foliated and jointed metamorphics. Its sinuous course cuts through the SSZ flowing south, and turns east receiving the waters of its principal tributary, the Kharkai, on its right bank, before taking a course due southeast. The river then alternates between a series of tight bends and straight reaches, holding its southeast course, before turning east again at Jamsola. Here the channel preferentially occupies a strike fault (Perumal et al. 1986), which cuts across the steeply dipping (towards northeast at angles of $60^{\circ}-70^{\circ}$ ) and intensely foliated quartzite beds of the Chaibasa Formation of the Singhbhum Group (originally comprising of the Singhbhum craton's supracrustal Palaeoproterozoic deposits of sandstone and shale which 

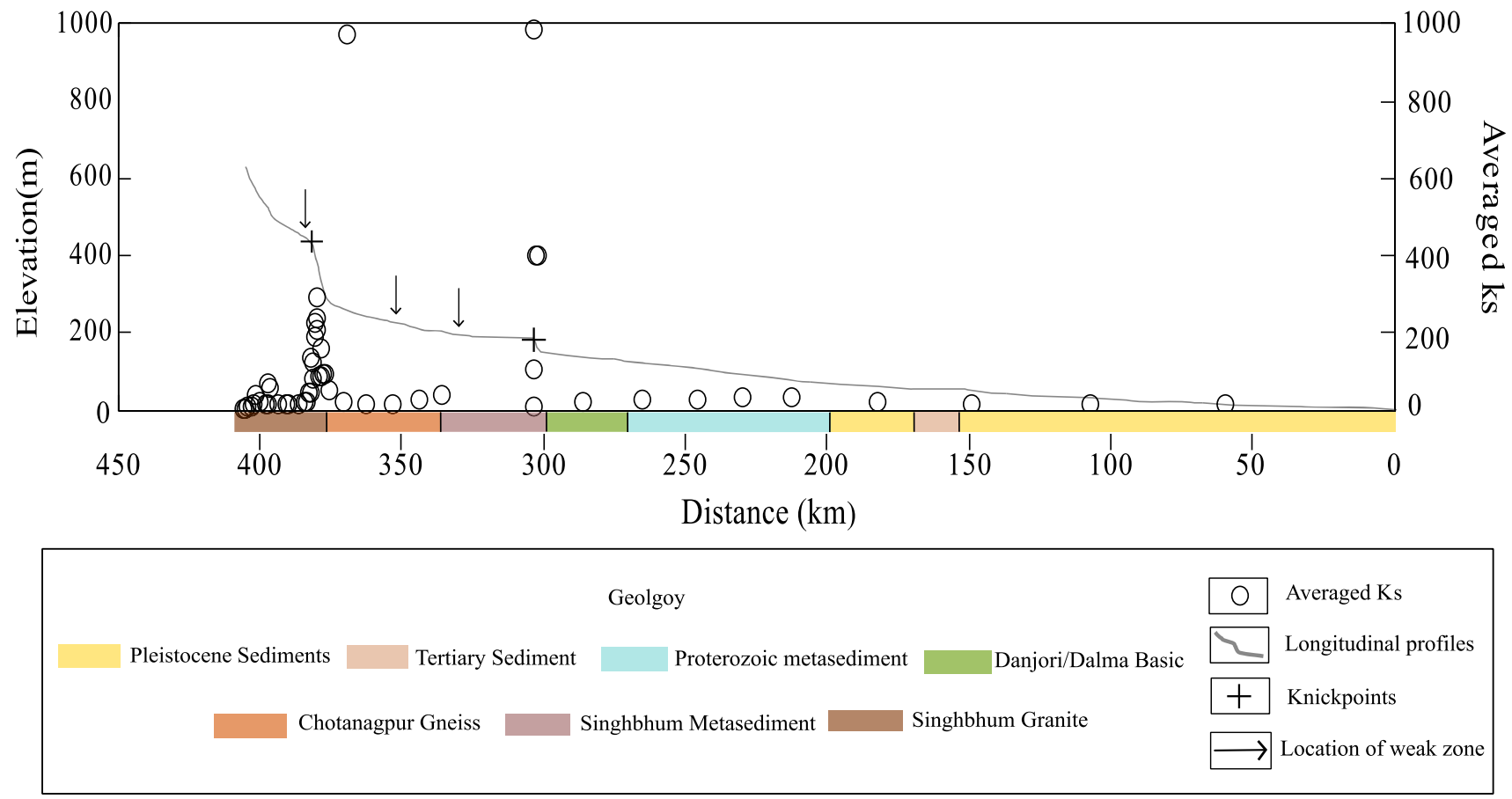

Figure 6. Longitudinal profile superimposed on the lithology and the structure. Average $k_{s n}$ values for the respective segments is also plotted on the same.

were metamorphosed into the present quartzite and mica-schist - Mazumder et al. 2012), into which the river duly incises, becoming deeply entrenched and narrowing considerably, while folds, plunging to the northeast, are also present along the banks, through which the river has carved its course (Rao 1962). This not only demonstrates the superposed nature of the main channel, but also how structural and lithologic variations have influenced the channel character herein.

In order to identify the role of surface lithology on the long profile development, we have superimposed the drainage lines and associated break in profiles over surface lithology (figure 6). Knickpoints, once formed, tend to migrate upstream by continual recession (Whipple and Tucker 1999). A distinct possibility behind the minor displacement of these knickpoints from the nearby lithostructural boundaries may therefore be the knickpoint migration process. Only the Johna Falls on the Gunga River coincides with the transition zone between the gneissic and ultra-basic rocks (figure 2, marked as J). However, the absence of observable lithological changes at the site may be ascribed to the aforesaid migration process. The other two mighty waterfalls in the upper portion of the basin do not coincide with any distinct lithological transition zone (figure 2 - Hundru Falls (marked $\mathrm{H})$ on the Subarnarekha River and the Dassam
Falls (marked D) on the Kanchi River). Planform observations of channel steepness from figure 7(a) reveals that the lithological transitions are not always associated with high $k_{s n}$ values. The lower $k_{s n}$ value segments are primarily present in three locales - in the gently undulating piedmont zone adjacent to the dissected plateau tract in the north, within the southern extents of the Kharkai River's sub-basin in the south-central part over a homogeneous lithology of Singhbhum granite and across the Quaternary deposits in the lower stretches of the Subarnarekha basin. The higher $k_{s n}$ value segments, on the other hand, are present along the northwestern tracts of the basin and along its central zone where a number of different lithologies have numerous interfaces along the SSZ.

It is evident from figure 8 that recent alluvium and laterites give rise to notably low $k_{s n}$ values which are constricted to the downstream or lower part of the basin. However, apparently, there is no systematic strong lithological control on the channel steepness as the median and interquartile range is similar in most of the substrate formations except for the Singhbhum granite (figure 8). The Kharkai basin is underlain by this uniform granite terrain which exhibits prolonged erosion and relatively stable topography. The Chotanagpur Gneissic Complex depicts the most heterogeneous distribution of $k_{s n}$ which is a sign of persistent 

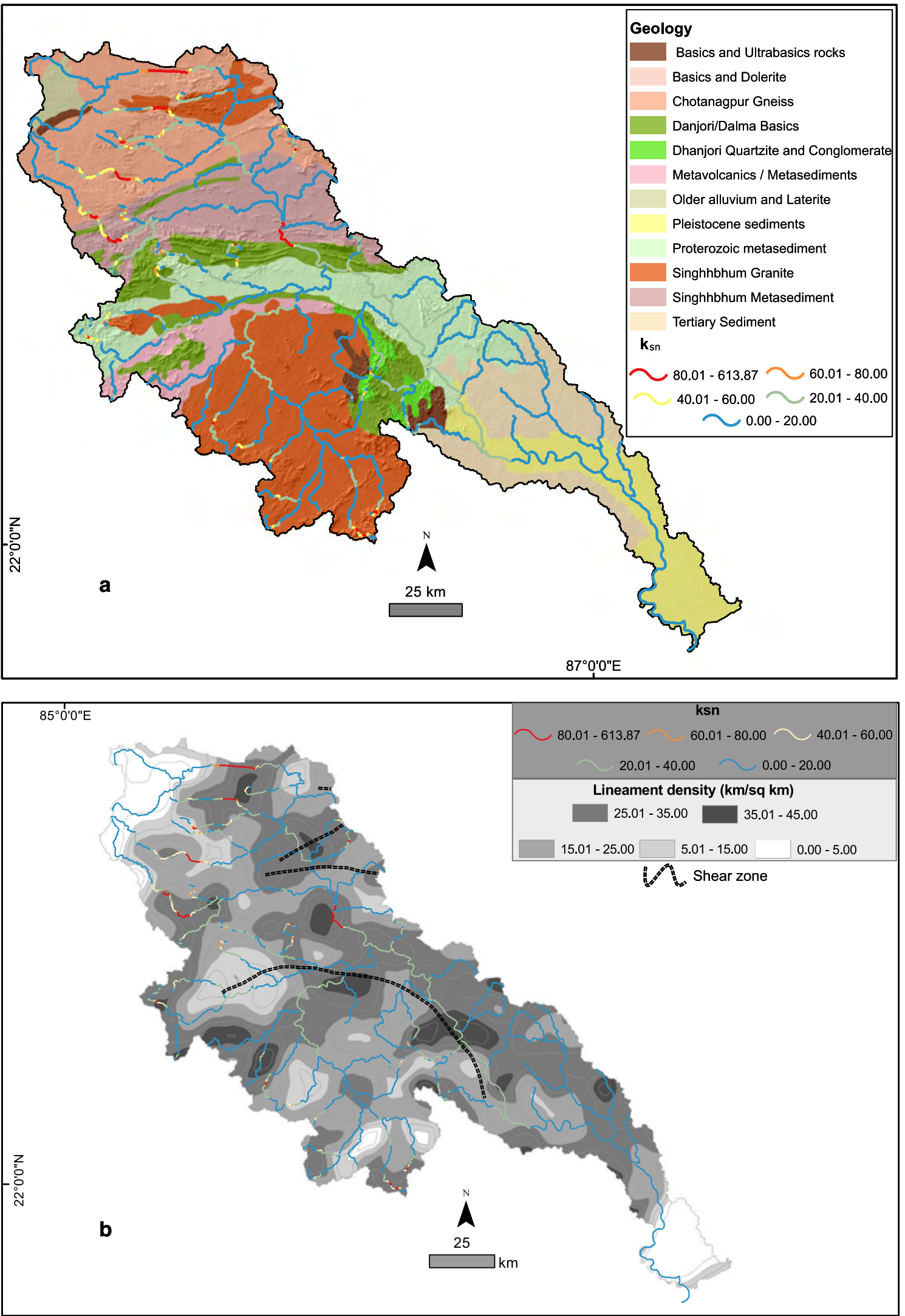

Figure 7. Lithological and structural control on the channel steepness. (a) Spatially varying $k_{s n}$ values overlain on the lithology map. (b) Lineament density map underlain by the spatially varying $k_{s n}$ values. 


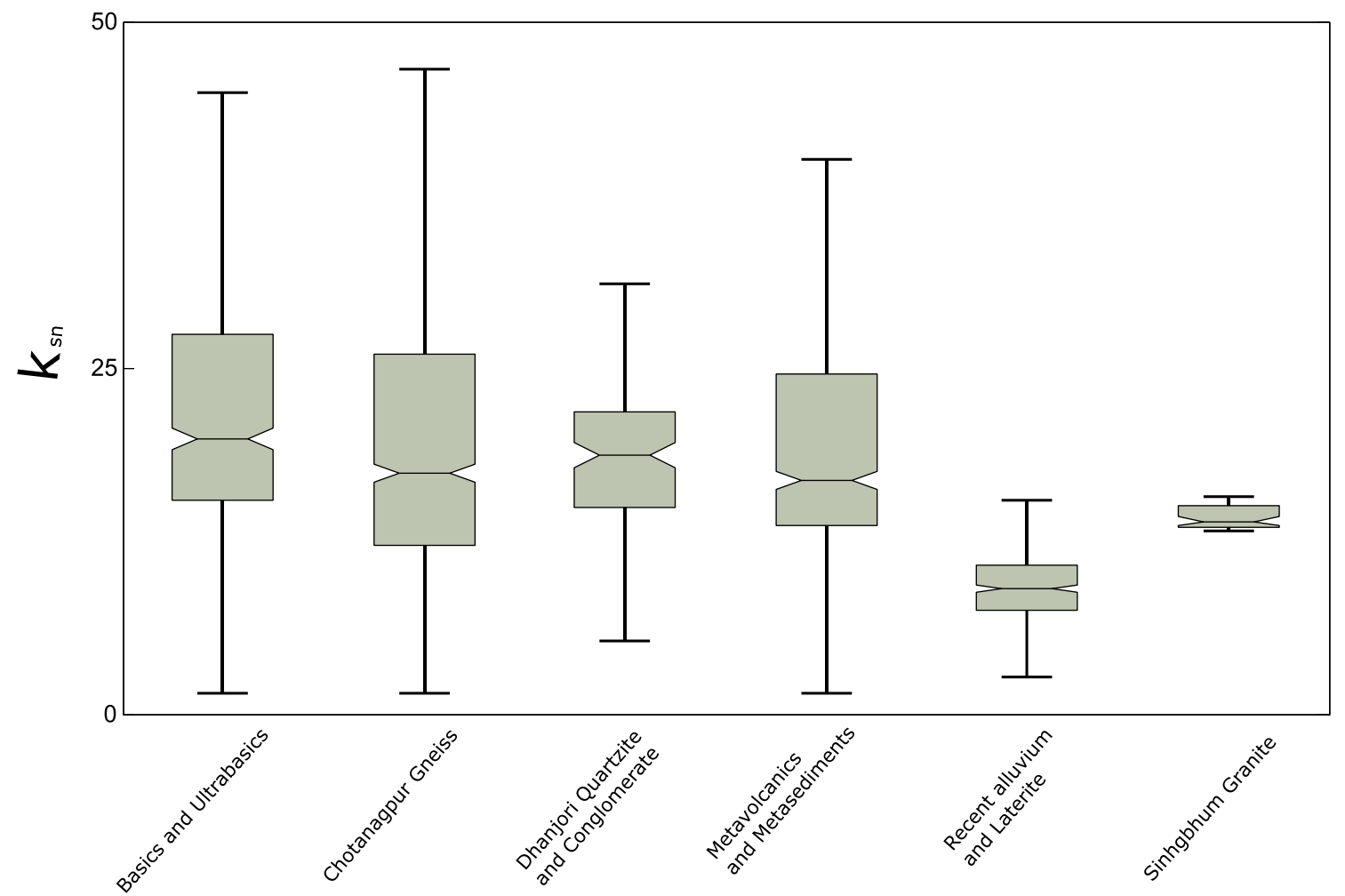

Figure 8. Box and whisker plots show the relative contribution of the bedrock geology on the segment-wise $k_{s n}$ map. Note that various geological units are collaborated into fewer ones to distinguish the relative importance of primary geologic units on the channel steepness index.

and slow deformation. Figure 7 is clearly showing that a linear continuous pattern of high $k_{s n}$ values have apparently no substrate control. Spatially distributed $k_{s n}$ values overlain on the shear zone in the lineament density map (figure 7b), illustrate two distinct zones associated with high $k_{s n}$. One such zone is present along the fringe of the Singhbhum plateau region, in the northern portion, where the topographic height difference controls the steepness. The other such region encompasses the Dalma Hill and the SSZ area in the central part of the basin, where the Subarnarekha River cuts through this range. Shear zones and active lineaments on the other hand, exert specific control on the drainage pattern and channel reach morphology, as the latter tends to follow and align itself according to the weak zones (figure 9 ).

Figure $7(\mathrm{~b})$ also shows that the high $k_{s n}$ values (in channel stretches which are incised and often have waterfalls and rapids), are notably associated with high lineament density. These waterfalls, which are mostly situated along the eastern margin of the Ranchi Highlands and in its extended sections further east (e.g., the Ajodhya Hills), are considered to have been formed initially as knickpoints of rejuvenation caused by uplift [e.g., Hundru on the Subarnarekha River and Dassam on the Kanchi River (Bharadwaj 2006) or as hanging valley falls, e.g., Johna, where the Gunga River hangs over its master stream, the Raru River (Bukhari 2006)], during a diastrophic phase that raised the ground along a line further to the east (Kumar 1982), but whose boundary has now receded westward due to continuous denudation, such that they are now along the edges of erosional scarps (Singh 1980). The polycylic nature of the basin's evolution is further reinforced by the identification of a number of paired terraces along the lower course of the river (Niyogi 1968; Mukhopadhyay 1973). A number of such palaeo-surfaces have also been previously identified from superimposition of SRTM DEM extracted surface profiles across the area on the basis of accordant summit levels (Patel and Sarkar 2010).

\subsection{Identification of transient state using chi plots}

The most important property of this coordinate transformation is that the same elevation has similar chi values in spite of having drainage areas of different magnitude. The chi-elevation plot, in general, deviates from a linear trend in case of 

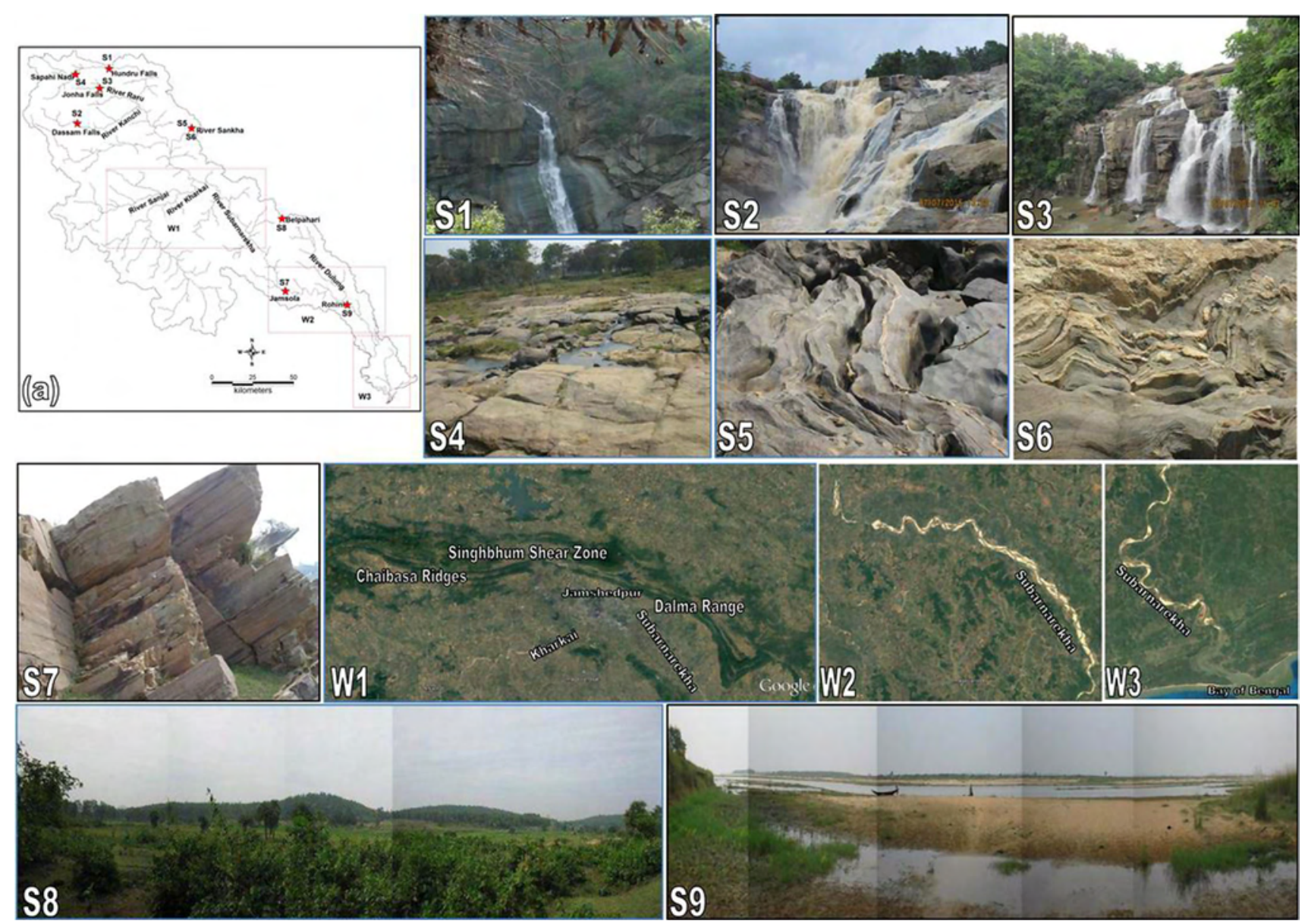

Figure 9. Channel morphology, riverbed structures and major waterfalls in the Subarnarekha River Basin with: (a) Inset map denoting the locations and extents of the various photographs or Google Earth image windows which are as follows. S1: The Hundru Falls on the River Subarnarekha; S2: The Dassam Falls on the River Kanchi; S3: The Jonha Falls on the River Gungu; S4: Rectangular jointing on the bed of the Sapahi River at its confluence with the Subarnarekha River just east of Ranchi; S5: Gouged out channels in bedrock by the Sankha River near Balarampur (Puruliya, West Bengal); S6: Folded gneiss on the Sankha River bed near Balarampur (Puruliya, West Bengal); S7: Steeply dipping foliated metamorphics at Jamsola which are superposed on by the Subarnarekha River; S8: Quartzite hill ranges of Belpahari which are the eastern continuation of the SSZ; S9: Wide sandy bed of the Subarnarekha River at Rohini (Paschim Medinipur, West Bengal); W1: The principal folded ranges of the SSZ around Jamshedpur where the Kharkai flows into the Subarnarekha, which has a constrained, sinuous bedrock channel along this entire stretch till Jamsola; W2: Change in bed material and channel morphology of the Subarnarekha after Jamsola, with the river having some meander loops and a broad sandy channel with extensive point and side bars; W3: The Subarnarekha's final stretch shows a series of meandering loops having alternating point bars.

contrasting lithological boundary or a change in the relative uplift rate (Perron and Royden 2013). Figure 10 clearly depicts a drastic deviation from the linear trend where downstream from the demarcated knickpoints, the slope of the chi-elevation plot increases. The derived chi values show a transient phase of erosion in the upper region for the main stream and two other tributaries. In general, there is apparently no significant difference in rock erodibility and other related parameters between the upstream and downstream reaches of these knickpoints. The only possibility of the disequilibrium might thus be a slow, ongoing process of uplift, whose rate, extent and influence is not constant spatially. The other tributaries have collapsed on to the main stream and this is projecting a steady state condition.

Further detailed analysis of statistical derivation constrains the stream power law more accurately as the chi values are plotted with the elevation data itself, which is less noisy than the slope data. Regression analysis shows that the $\mathrm{m} / \mathrm{n}$ ratio for the best fit model $\left(R^{2}=0.83\right)$ is 0.59 with the reference drainage area $A_{0}=1 \mathrm{~km}^{2}$. 


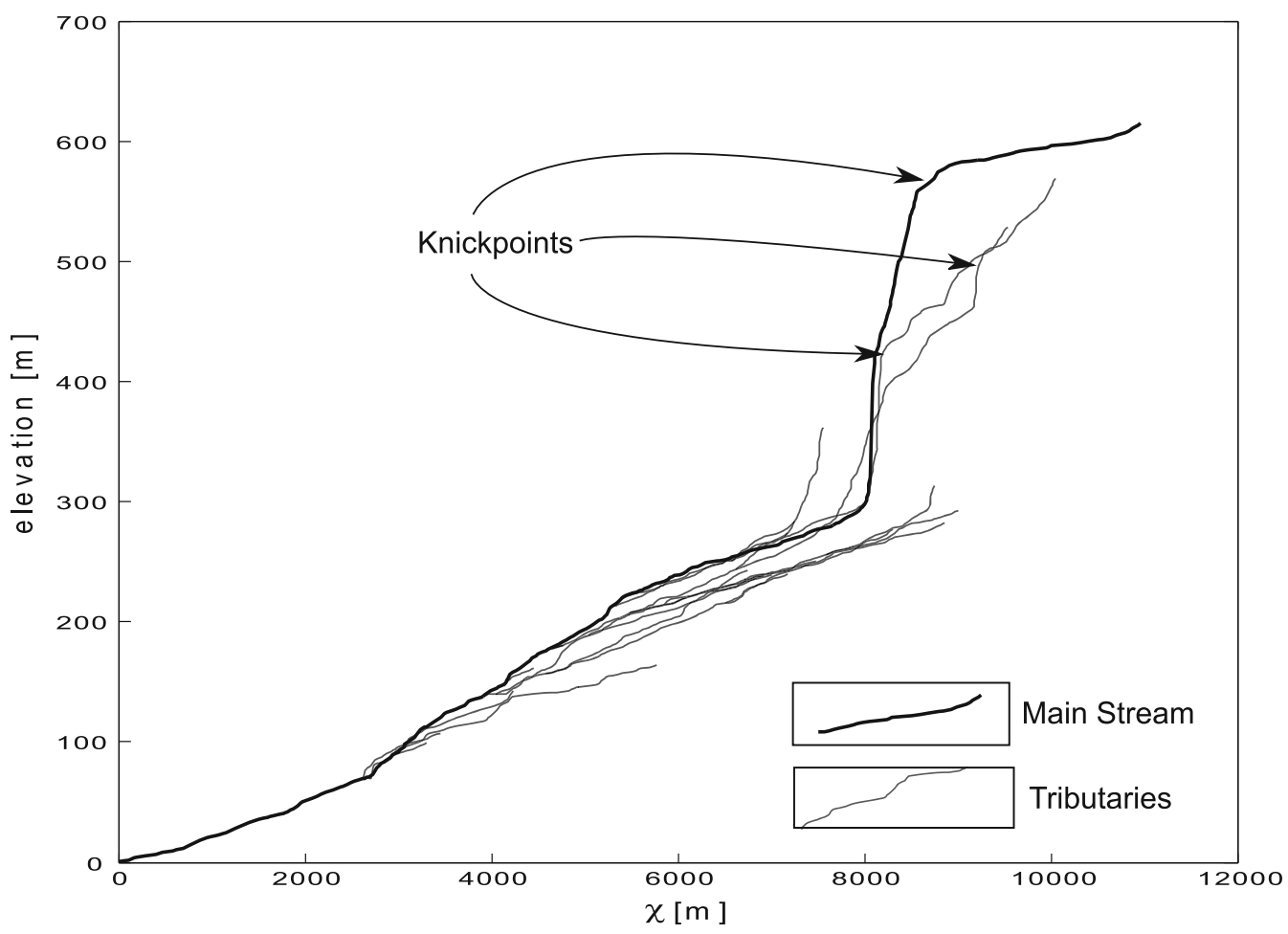

Figure 10. Composite chi plot of the principal and tributary stream courses.

Table 3. Global autocorrelation with the help of Moran's I test for different grid sizes.

\begin{tabular}{lcclc}
\hline Grid size & $I$ & $E(I)$ & \multicolumn{1}{c}{$z$} & \multicolumn{1}{c}{$p$} \\
\hline $1 \mathrm{~km}$ & 0.118 & -0.0001 & 207.02 & 0.0001 \\
$2 \mathrm{~km}$ & 0.1767 & -0.0002 & 83.6387 & 0.0001 \\
$5 \mathrm{~km}$ & 0.2686 & -0.0011 & 29.8753 & 0.0001
\end{tabular}

$I$ : Moran's $I, E(I)$ : expected value for considering the random distribution, $z: \mathrm{z}$ score, $p$ : probability of the randomness of the data.

The slope of the regression line is 0.14. The erodibility of different lithological units is different as it depends on various inherent properties like the rock's hardness, density, compactness, and thereby give differing erodibility coefficients of $10^{-7}-10^{-6} \mathrm{~m}^{-0.2} / \mathrm{yr}$ for granite and metamorphic rocks to $10^{-5}-10^{-4} \mathrm{~m}^{0.2} / \mathrm{yr}$ for volcaniclastic rocks (Stock and Montgomery 1999). Considering these values, the uplift rate can be inferred in a range of $0.04-4 \mathrm{~mm} /$ year for granite--metamorphic rocks and volcaniclastic rocks, respectively. However, the rates inferred from this modelling can be erroneous due to the differential and complex uplift pattern across spatial scales and from the heterogeneity of geological conditions.

\subsection{Spatial autocorrelation of gridded HI and its implication to the tectonic or lithological setting}

Grid-wise HI values, considering discrete grid cells, provide a picture of the spatially varying erosional competence within the drainage basin. Often the distribution of the $\mathrm{HI}$ values is random in nature because of the local topographic factors associated with the grid resolution. Therefore, the data has to be tested to examine whether any spatial association truly exists or not. For this purpose, we have used various statistical techniques to test the spatial autocorrelation.

The Moran's $I$ is calculated for different grid sizes of dimension 1,2 and $5 \mathrm{~km}$, respectively, to check the scale dependence on the statistical techniques. The ensuing exercise has affirmed that for all three cases, the $z$ score is considerably higher each time and decreases as the grid size increases (table 3). Higher $z$ scores suggest that there is indeed a spatial autocorrelation of the HI values in the Subarnarekha River basin. This variability in terms of hypsometry for the gridded area cannot be therefore illustrated as an indicator of tectonics or lithological difference (see supplementary figure S3). 

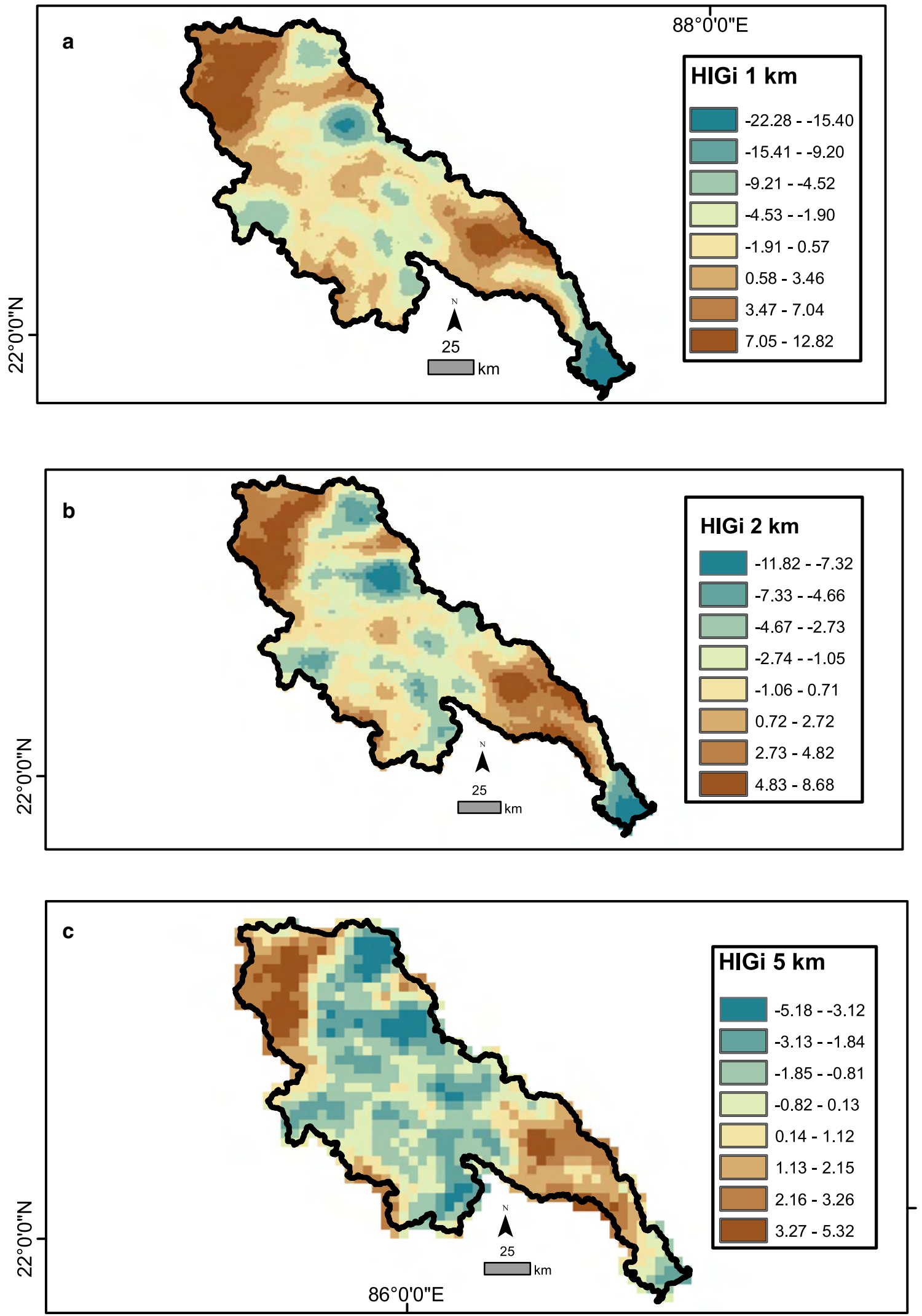

Figure 11. Grid-wise Getis-Ord $G_{i}$ statistics values representing clustering of hypsometric integrals derived across the basin surface at grid dimensions of (a) $1 \mathrm{~km}$, (b) $2 \mathrm{~km}$ and (c) $5 \mathrm{~km}$. 
However, the $G_{i}$ statistics map depicts well defined high and low clusters of HI value, wherein two distinct zones of high HI value cluster have been identified (figure 11). The prominent reason for the high HI values in these grids is the lower amount of terrain dissection. This less dissection is generally attributed to either increased tectonic uplift or to the presence of a resistant rock cover. In the upstream region, the distinct and abrupt change in the high HI value cluster zone lies within the gneissic terrain, similar in lithology to its surroundings, thus implying that it is in fact a slow and steady endogenic perturbation, rather than lithological differences, which is the driving factor herein. Here the river has also bent sharply to the south from its initial eastward direction, possibly as a result of stream piracy (Mahadevan 2002). In the downstream region, there is another cluster of high HI values overlain on the Tertiary and Pleistocene sediments. The elevation distribution of the downstream region is certainly relatively quite low, depicting quite negligible or no regional tectonic uplift. Therefore, this anomalous pattern can be attributed to relatively lesser dissection herein due to Cenozoic sedimentation and its partial protection by a lateritic duricrust caprock (e.g., as is seen in the Lalgarh formation along the eastern fringe of the basin), along with the presence of NW-SE trending low hills of schist, phyllite and resistant quartzite. The higher HI cluster here is thus more lithologically induced.

\section{Conclusion}

The Singhbhum craton is one of the oldest surfaces in the world, with an age of more than $3.12 \mathrm{Ga}$ (Misra and Johnson 2005), wherein the documentation of more recent tectonic activities is scant. In the present study, a thorough analysis of the morphometric parameters along with the structural characteristics confirms an ongoing slow tectonic deformation within the Subarnarekha River basin. The dearth of absolute dating techniques retards the quantification of the Quaternary uplift and incision rates, but the overall pattern implies an apparently steady tectonic uplift in the upstream sections of the drainage area. It is further corroborated with the existing literature that the longitudinal profile forms of the streams flowing across this surface provides one of the most sensitive gauges of the changes in relative motion and elevation of the surface, as they record these deformations in terms of anomalies in their respective profiles (Han and Choi 2014), being salient indicators of neotectonic activity in an otherwise ancient landscape. These anomalies, as marked by the breaks or knickpoints along these streams' courses, correlate strongly with existing structural and some, albeit much fewer, lithological boundaries as well. The majority of such knicks are observed along the scarp line forming the transition zone between the eastward extensions of the Chotonagpur Plateau's dissected tracts and ranges, and the lower elevation plains that abut it to the south and east, implying a possible tectonic movement, further modified by erosion induced recession of initial fall lines. Their considerable height till today, further demonstrates that uplifting forces are still active over the Chotanagpur plateau as a whole (Mahadevan 2002), reinforcing the need for such investigations. This is ratified by the occurrence of recent earthquakes, albeit gentle ones, whose foci lie within or around the periphery of the Subarnarekha Basin (e.g., the 2005 tremor near Ghatshila of magnitude 3.8 - information acquired from http://www.isc. ac.uk). Statistical clustering reveals groupings of high and low hypsometric values, implying that the denudation of this landscape has not been uniform. While this is to be expected, in the light of a raft of diverse natural processes acting across a variety of lithologies and thereby resulting in varied erosional rates, the coupling of this phenomenon with the afore mentioned surmises obtained from the analysis of stream profiles, can lead to the postulate that the overall landscape has responded in a piece-meal manner to the uplifts suffered by it. Such piecemeal responses are likely to be governed by locally varying thresholds, which may be further delved into on basis of more detailed field-based investigations. This study, using DEM extracted information, representing such responses qualitatively and correlating them quantitatively with the underlying litho-structural matrix, serves to pinpoint the probable sites of such detailed investigations, which would elicit more information on the readjustments in an otherwise ancient landscape. As such, this work provides both, an insight into the present study area's geological dynamics and a methodology that may be applicable to other such areas.

\section{Acknowledgements}

The authors gratefully acknowledge the contribution of some students of the Department of Geography, Presidency University, Kolkata, (namely, 
Mr Pranav Pratik, Mr Jayesh Mukherjee, Mr Soumik Das and Mr Biman Biswas), who willingly provided some of the field photographs of the various waterfalls within the Subarnarekha River Basin. Authors are grateful to Prof. Chalapathi Rao and the anonymous reviewer for their constructive reviews and suggestions which improved the clarity of an earlier version of this paper.

\section{References}

Abdullah S N and Abdoh G A 2013 Landsat ETM-7 for lineament mapping using automatic extraction technique in the SW part of Taiz Area, Yemen; Glob. J. Hum.-Soc. Sci. Res. 13 35-37.

Ahmadi R, Ouali J, Mercier E, Mansy J-L, Lanoë B V-V, Launeau P, Rhekhiss F and Rafini S 2006 The geomorphologic responses to hinge migration in the fault-related folds in the southern Tunisian Atlas; J. Struct. Geol. 28 $721-728$

Ambili V and Narayana A C 2014 Tectonic effects on the longitudinal profiles of the Chaliyar River and its tributaries, southwest India; Geomorphology 217 37-47.

Azañón J M, Galve J P, Pérez-Peña J V, Giaconia F, Carvajal R, Booth-Rea G, Jabaloy A, Vázquez M, Azor A and Roldán F J 2015 Relief and drainage evolution during the exhumation of the Sierra Nevada (SE Spain): Is denudation keeping pace with uplift?; Tectonophys. 663 19-32.

Banerji A K, Mitra S K and Mukhopadhyaya S C 1970 Tectonic sequence in the Sini-Saraikela region, Singhbhum district; Quart. J. Geol. Min. Met. Soc. India 42 141149 .

Bharadwaj K 2006 Physical Geography: Hydrosphere; Discovery Publishing House, New Delhi.

Bookhagen B and Burbank D W 2010 Toward a complete Himalayan hydrological budget: Spatiotemporal distribution of snowmelt and rainfall and their impact on river discharge; J. Geophys. Res. Earth Surf. 115 F03019.

Bookhagen B and Strecker M W 2008 Orographic barriers, high-resolution TRMM rainfall, and relief variations across the eastern Andes; Geophys. Res. Lett. 35 L06403.

Brunsden D and Thornes J B 1979 Landscape sensitivity and change; Trans. Inst. Br. Geogr. 4 463-484.

Bukhari A Z 2006 Encyclopedia of Nature of Geography; Anmol Publications Pvt Ltd., New Delhi.

Burbank D W and Anderson R S 2011 Tectonic Geomorphology; John Wiley \& Sons, New Jersey.

Burbank D W, Leland J, Fielding E, Anderson R S, Brozovic N, Reid M R and Duncan C 1996 Bedrock incision, rock uplift and threshold hillslopes in the northwestern Himalayas; Nature 379 505-510.

Chatterjee S, Krishna A P and Sharma A P 2014 Geospatial assessment of soil erosion vulnerability at watershed level in some sections of the Upper Subarnarekha river basin, Jharkhand, India; Environ. Earth Sci. 71 357-374.

Colberg J S and Anders A M 2014 Numerical modeling of spatially-variable precipitation and passive margin escarpment evolution; Geomorphology 207 203-212.
Dandapat K and Panda G K 2013 Drainage and floods in the Subarnarekha Basin in Paschim Medinipur, West Bengal, India - a study in applied geomorphology; Int. J. Sci. Res. 4 791-797.

Duncan C, Masek J and Fielding E 2003 How steep are the Himalaya? Characteristics and implications of alongstrike topographic variations; Geology 31 75-78.

England P and Molnar P 1990 Surface uplift, uplift of rocks, and exhumation of rocks; Geology 18 1173-1177.

Flint J J 1974 Stream gradient as a function of order, magnitude, and discharge; Water Resour. Res. 10 969-973.

Gassman P W, Reyes M R, Green C H and Arnold J G 2007 The soil and water assessment tool: Historical development, applications, and future research directions; Trans. $A S A B E \mathbf{5 0}$ 1211-1250.

Geomatics P C I 2015 Tutorials; PCI Geomatics, Richmond Hill, Cannada.

Giri S, Singh A K and Tewary B K 2013 Source and distribution of metals in bed sediments of Subarnarekha River, India; Environ. Earth Sci. 70 3381-3392.

Hack J T 1973 Stream profile analysis and stream-gradient index; J. Res. U.S. Geol. Surv. 1 421-429.

Han J G and Choi S J 2014 Stream analysis of small drainage basins in an ancient landform, Korean Peninsula; J. Asian Earth Sci. 95 323-330.

Harbor D and Gunnell Y 2007 Along-strike escarpment heterogeneity of the Western Ghats: A synthesis of drainage and topography using digital morphometric tools; Geol. Soc. India 70 411-426.

Haviv I, Enzel Y, Whipple K X, Zilberman E, Matmon A, Stone J and Fifield K L 2010 Evolution of vertical knickpoints (waterfalls) with resistant caprock: Insights from numerical modeling; J. Geophys. Res. Earth Surf. 115.

Howard A D 1994 A detachment-limited model of drainage basin evolution; Water Resour. Res. 30 22612285 .

Howard A D and Kerby G 1983 Channel changes in badlands; Geol. Soc. Am. Bull. 94 739-752.

Kale V S, Achyuthan H and Sengupta S 2010 Reconstruction of Late Quaternary Fluvio-sedimentary response of Kaveri and Palar Rivers: based on Chronostratigraphy, Digital Geomorphometry and Remote Sensing Analysis. University of Pune, Pune.

Kale V S and Shejwalkar N 2007 Western Ghat escarpment evolution in the Deccan basalt province: Geomorphic observations based on DEM analysis; Geol. Soc. India $\mathbf{7 0}$ 459-473.

Kocal A, Duzgun H S and Karpuz C 2007 An accuracy assessment methodology for the remotely sensed discontinuities: A case study in Andesite Quarry area, Turkey; Int. J. Rem. Sens. 28 3915-3936.

Kumar P 1982 Diastrophic forces and their geomorphic expression in Ranchi Plateau; In: Perspectives in Geomorphology (ed.) Sharma H S, Concept Publishing Company, New Delhi 4 195-210.

Lee C S and Tsai L L 2010 A quantitative analysis for geomorphic indices of longitudinal river profile: A case study of the Choushui River, Central Taiwan; Environ. Earth Sci. 59 1549-1558. 
Lima A G and Binda A L 2013 Lithologic and structural controls on fluvial knickzones in basalts of the Paraná Basin, Brazil; J. South Am. Earth Sci. 48 262-270.

Lin Z and Oguchi T 2006 DEM analysis on longitudinal and transverse profiles of steep mountainous watersheds; Geomorphol. 78 77-89.

Mahadevan T M 2002 Text Book Series 14: Geology of Bihar and Jharkhand; Geol. Soc. India, Bangalore.

Mandal S K, Lupker M, Burg J P, Valla P G, Haghipour $\mathrm{N}$ and Christl M 2015 Spatial variability of $10 \mathrm{Be}-$ derived erosion rates across the southern Peninsular Indian escarpment: A key to landscape evolution across passive margins; Earth Planet. Sci. Lett. 425 154-167.

Mazumder R, Van Loon A J, Mallik L, Reddy S M, Arima M, Altermann W, Eriksson P G and De S 2012 Mesoarchaean-Palaeoproterozoic stratigraphic record of the Singhbhum crustal province, eastern India: A systhesis; Geol. Soc. London, Spec. Publ. 365 31-49.

Misra S and Johnson P T 2005 Geochronological constraints on evolution of Singhbhum mobile belt and associated basic volcanics of eastern Indian shield; Gondwana Res. 8 129-142.

Molin P and Corti G 2015 Topography, river network and recent fault activity at the margins of the Central Main Ethiopian Rift (East Africa); Tectonophys. 664 67-82.

Moran P A 1950 Notes on continuous stochastic phenomena; Biometrika 37 17-23.

Mukhopadhyay S C 1977 Geomorphology of a part of the lower Kharkai basin; Geogr. Rev. India 39 248-258.

Mukhopadhyay S C 1973 River terraces of Subernarekha Basin; Geogr. Rev. India 35 152-170.

Nag S K and Chakraborty S 2003 Influence of rock types and structures in the development of drainage network in hard rock area; J. Indian Soc. Remote Sens. 31 25-35.

Niyogi D 1968 Morphology of the terraces of the Subarnarekha river, India; In: Selected papers 21st International Geographical Congress, pp. 84-88.

Ord J K and Getis A 1995 Local spatial autocorrelation statistics: Distributional issues and an application; Geogr. Anal. 27 286-306.

Patel P P and Sarkar A 2010 Terrain characterization using SRTM data; J. Indian Soc. Rem. Sens. 38 11-24.

Pérez-Peña J V, Azañón J M, Booth-Rea G, Azor A and Delgado J 2009 Differentiating geology and tectonics using a spatial autocorrelation technique for the hypsometric integral; J. Geophys. Res. Earth Surf. 114.

Perron J T and Royden L 2013 An integral approach to bedrock river profile analysis; Earth Surf. Process. Landf. 38 570-576.

Perumal N V A S, Kak S N and Katti V J 1986 Integrated remote sensing approach to uranium exploration in India; In: Atomic Energy Agency (ed.) Geological Data Integration Techniques: Proc. Technical Committee Meeting of the International Atomic Energy Agency, No. IAEA-TECDOC-472, International Atomic Energy Agency, Vienna, pp. 131-164.

Phillips J D 1998 Earth surface systems: Complexity, order, and scale; Blackwell Publishers, Oxford.

Prasad A D, Jain K and Gairola A 2013 Mapping of lineaments and knowledge base preparation using geomatics techniques for part of the Godavari and Tapi basins, India: A case study; Int. J. Comput. Appl. 70 39-47.
Prince P S, Spotila J A and Henika W S 2011 Stream capture as driver of transient landscape evolution in a tectonically quiescent setting; Geology 39 823-826.

Raj K S and Ahmed S A 2014 Lineament extraction from southern Chitradurga Schist belt using Landsat TM, ASTER GDEM and geomatics techniques; Int. J. Comput. Appl. 93 12-20.

Rao M G 1962 Investigation of manganese and other mineral occurrences in Midnapore District, West Bengal, Progress Report for the Season 1961-1962 (GSI-CHQ-1226); Geological Survey of India, Kolkata.

Reusser L J, Bierman P R, Pavich M J, Zen E, Larsen J and Finkel R 2004 Rapid late Pleistocene incision of Atlantic passive-margin river gorges; Science 305 499-502.

Saha A K 1994 Crustal evolution of Singhbhum-North Orissa, eastern India; Geol. Soc. India Memoir, Geological Survey of India, Kolkata 27341.

Sangode S J, Meshram D C, Kulkarni Y R, Gudadhe S S, Malpe D B and Herlekar M A 2013 Neotectonic response of the Godavari and Kaddam rivers in Andhra Pradesh, India: Implications to quaternary reactivation of old fracture system; J. Geol. Soc. India 81 459-471.

Sarkar A N 1982 Structural and petrological evolution of the Precambrian rocks in western Singhbhum, Bihar; Geol. Surv India Memoirs, Geological Survey of India, Kolkata 113 97p.

Schwanghart W and Kuhn N J 2010 TopoToolbox: A set of Matlab functions for topographic analysis; Environ. Model. Softw. 25 770-781.

Shankar B, Tornabene L L, Osinski G R, Roffey M, Bailey J M and Smith D 2016 Automated lineament extraction technique for the sudbury impact structure using remote sensing datasets - An update; In: Proc. 47th Lunar and Planetary Science Conf., Texas 471424.

Singh O P 1980 Geomorphology of drainage basins in Palamau upland; Recent Trends Concepts Geogr. 1 229-247.

Sklar L and Dietrich W E 1998 River longitudinal profiles and bedrock incision models: Stream power and the influence of sediment supply; In: Rivers over Rock: Fluvial Processes in Bedrock Channels (eds) Tinkler K J and Wohl E, American Geophysical Union, Washington D.C., pp. 237-260.

Snyder N P, Whipple K X, Tucker G E and Merritts D J 2000 Landscape response to tectonic forcing: Digital elevation model analysis of stream profiles in the Mendocino triple junction region, northern California; Geol. Soc. Am. Bull. 112 1250-1263.

Stock J D and Montgomery D R 1999 Geologic constraints on bedrock river incision using the stream power law; $J$. Geophys. Res. B104 4983-4993.

Strecker M R, Hilley G E, Arrowsmith J R and Coutand I 2003 Differential structural and geomorphic mountainfront evolution in an active continental collision zone: The northwest Pamir, southern Kyrgyzstan; Geol. Soc. Am. Bull. 115 166-181.

Tarboton D G, Bras R L and Rodriguez-Iturbe I 1991 On the extraction of channel networks from digital elevation data; Hydrol. Process. 5 81-100.

Thomas M F 2001 Landscape sensitivity in time and space - an introduction; Catena 42 83-98.

Thornbury W D 1954 Principles of Geomorphology, Wiley \& Sons, New York. 
Valdiya K S 2001 Tectonic resurgence of the Mysore plateau and surrounding regions in cratonic southern India; Curr. Sci. 81 1068-1089.

Whipple K X and Tucker G E 1999 Dynamics of the streampower river incision model: Implications for height limits of mountain ranges, landscape response timescales, and research needs; J. Geophys. Res. Solid Earth 104 17,66117,674 .

Whipple K X, Wobus C, Kirby E, Crosby B and Sheehan D 2007 New tools for quantitative geomorphology: Extraction and interpretation of stream profiles from digital topographic data; Short Course presented at the Geological Society of America Annual Meeting, Denver, CO.

Willett S D, McCoy S W, Perron J T, Goren L and Chen C Y 2014 Dynamic reorganization of river basins; Science 3431248765.

Corresponding editor: N V CHALAPATHI RAO
Willgoose G, Bras R L and Rodriguez-Iturbe I 1991 A coupled channel network growth and hillslope evolution model: 1. Theory; Water Resour. Res. 27 16711684.

Wobus C W, Crosby B T and Whipple K X 2006a Hanging valleys in fluvial systems: Controls on occurrence and implications for landscape evolution; J. Geophys. Res. Earth Surf. 111.

Wobus C W, Whipple K X, Kirby E, Snyder N, Johnson J, Spyropolou K, Crosby B and Sheehan D 2006b Tectonics from topography: Procedures, promise, and pitfalls; Geol. Soc. Am. Spec. Paper 398 55-74.

Yarrakula K, Deb D and Samanta B 2010 Hydrodynamic modeling of Subernarekha River and its floodplain using remote sensing and GIS techniques; J. Sci. Ind. Res. 69 $529-536$. 